\title{
Draci a hrdinové - upíri a oběti (hledání magických bytostí ve světě vědy a techniky)
}

\author{
Markéta Poláková \\ Katedra teorie kultury (kulturologie) Filozofické fakulty Univerzity Karlovy v Praze, Celetná 20, 11000 Praha 1 \\ Do redakce doručeno 18. srpna 2011; k publikaci přijato 26. října 2011
}

\author{
DRAGONS AND HEROES - VAMPIRES AND VICTIMS \\ (SEARCHING MAGIC BEINGS IN THE WORLD OF SCIENCE AND TECHNIQUE)
}

\begin{abstract}
The theme of this contribution is an analysis of searching magic beings, dragons and vampires, in the postmodern world of science and technique. At first sight, it could seem these beings, so far away from rationalism of present time, cannot find their real expression. The aim of this study is to describe which way the stories about monsters, their victims and heroes, who come to save them, has adapted to the cultural code of present time. How much have dragons and vampires kept their former identity and how much have the differences between a hero and a monster started to remove? Special attention is paid to the phenomenon of the role playing games and current image of a literary vampire, and even gender differences in the approach to the fantastic beings was taken into account.
\end{abstract}

KEY WORDS dragons; vampires; heroes; role playing games; fantasy; culture; gender

\begin{abstract}
ABSTRAKT Tématem tohoto př́spěvku je analýza hledání magických bytostí draků a upírů v postmoderním světě vědy a techniky. Na první pohled se může zdát, že tyto bytosti, tak vzdálené od racionalismu dnešní doby, nemohou nalézt své reálné vyjádření. Cílem této studie je popsat, jakým způsobem se př́běhy o monstrech, jejich obětech a hrdinech, které je přicházejí zachránit, přizpůsobily kulturnímu kódu dnešní doby. Nakolik si draci a upíri uchovali svou původní identitu a nakolik se rozdíly mezi hrdinou a monstrem začaly stírat? Zvláštní pozornost je věnovaná fenoménu role playing games a dnešní podobě literárního upíra, přičemž jsou zde zohledněny i genderové rozdíly v přístupu $\mathrm{k}$ těmto fantastickým bytostem.
\end{abstract}

KLÍČOVÁ SLOVA draci; upírí; hrdinové; role playing games; fantasy; kultura; gender

\section{ÚVOD}

Noc v úplňku, pochmurné hřbitovy, ruiny opuštěné kaple, temné jeskyně, polorozbořené hrady či staré domy, jejichž okenice skřípají v poryvech větru ... Lidé si od nejstarších dob vyprávěli o magických bytostech, které jsou spjaté s místy vyvolávajícími atmosféru neklidu a hrůzy. V těchto příbězích se pak ale zároveň mnohdy vyskytovala postava statečného hrdiny, který plnil nebezpečné úkoly, přemohl monstra a prošel všemi překážkami. Zničil všechny krvelačné upíry, draky i další nebezpečné bytosti. Kde jsou ale dnes? Racionalismus současné doby nedovoluje starým příběhům o monstrech, jejich obětech a statečných hrdinech uvěřit, přesto se s nimi v pozměněné podobě setkáváme i dnes. Nakolik se museli přizpo̊sobit kulturnímu kódu dnešní doby? Předmětem této studie je analýza hledání fantastického světa děsivých draků a upírů v moderní západní společnosti.

\section{OHROŽENÝ DRUH?}

Síla starých mýtů a pověstí byla potlačovaná nejdříve katolickou církví, poté osvícenským racionalismem, moderní vědou a průmyslovou revolucí. S tím, jak lidé začali preferovat život ve městech, nechávali za sebou i všechny ty nadpřirozené bytosti, které se staly pouhými „babskými“ povídačkami a pohádkami pro malé děti. Jak se zmiňuje Evženie Mádrová, moderní doba „odkouzlila“ tradiční svět. Zbavila ho magie, tajemství, mýtů a začala budovat svou sociální skutečnost na základě stř́zlivých, věcných, praktických a vysoce účelných zásad. Na místo mytických (a později teologických) výkladů existence nastoupila věda, která už nepopisuje svět pohledně, jako to činily mýty (Mádrová 2004, 45). S teorií „odkouzlení "světa se setkáváme už u německého sociologa a ekonoma Maxe Webera (1864-1920), který se zmiňoval o tom, že se ze světa vytratila veškerá mystika a život začal mít 
ryze intelektuální povahu. Racionalita pak proniká do všech sfér sociálního života, v nichž se účastníci orientují výhradně podle svých účelových zájmů (viz Weber 1998, 172-245). Ve světě vědy, techniky a průmyslu, zbaveného kouzla, lidem ale upíri, draci, jednorožci či vlkodlaci začali chybět. Potřebovali je vrátit do svých životů tak, aby dosáhli konsensu ve snění o jejich existenci a zároveň mohli dál žít svým moderním racionálním životem. Upíri a draci známí z mýtů, pohádek a pověstí tedy nevymřeli, ale přizpůsobili se měnící se společnosti, aby následně ožili ve světě fantasy. Fantasy lze definovat jako moderní literární, filmový, výtvarný a herní žánr, který se utvářel zejména od tř̌icátých let minulého století v anglicky mluvících zemích, převážně na stránkách časopisů publikujících nenáročnou literaturu. Rozhodujícím způsobem vývoj fantasy ovlivnil výpravný román The Lord of the Rings (Pán prstenů) britského spisovatele Johna Ronalda Reuela Tolkiena (1892-1973), který poprvé vyšel v padesátých letech minulého století. Samotný Tolkien se o potřebě zasazení fantaskních postav do našich životů zmiňuje slovy: "Měli bychom opět pohlédnout do zelené barvy a nechat se vyburcovat modrou, žlutou a červenou. Měli bychom potkat kentaura i draka a pak možná znenadání, tak jako dávní pastýři, spatřit ovce, psy, koně - a vlky" (Tolkien 1997, 131). Fantasy se většinou odehrává ve světě založeném na principu magie a jiných nadpřirozených jevů. Směrů žánru fantasy je mnoho, ale i když se odlišují svou poetikou, spojuje je idea světa, ve kterém žijí různí bájní tvorové a bytosti (draci, vlkodlaci, upírii, jednorožci, elfové či trpaslíci). V tomto světě neodmyslitelnou roli hraje magie a čarodějnictví. Tato studie se zaměřuje na postmoderní svět draků a upírů se zvláštním důrazem na genderové odlišnosti, které jsou s nimi spojeny. V souvislosti s tím lze hovořit také o epické a urbánní fantasy. V epické neboli hrdinské fantasy se objevují př́běhy o hrdinovi, který prožívá nejrůznější dobrodružství ve smyšleném světě, mnohdy se střetává s nadpřirozenými silami a jeho cesta často vrcholí bojem s drakem či jinou nestvưrou. Oproti tomu v urbánní fantasy přicházejí magické a nadpřirozené bytosti do měst, ve kterých žijeme. Pro čtenáře/hráče/diváky obou těchto poddruhů fantasy žánrů je však charakteristické silné prožívání ,jiných“, paralelních světů plných magie a nevšedních až nebezpečných situací prvků, které jim chybějí v běžném životě.

\section{CESTA HRDINY A MOTIV ZABITÉHO DRAKA}

Drak ožíval v příbězích, legendách, pohádkách a pověstech celého světa. S jeho vyobrazením se setkáváme od starověku, přes antiku a středověk, stejně tak i v dnešní době. V období renesance a baroka byla existence draků jako živočišných druhů pobývajících ve vzdálených romantických končinách pokládaná za samozřejmou. Např́klad Cosmographia německého hebreisty a kosmografa Sebastiana Münstera (1488-1552) z roku 1544 uvádí, že drak bazilišek, který má jed silnější než hadi, žije v Africe v oblasti Cyrene. Je tak nebezpečný, že dokáže zahubit nepřítele pouhou svou přítomností. Existenci dravých létajících plazů ovšem v 18. století výrazně zpochyb- nil švédský přírodovědec a lékař Carl von Linné (1707-1788), když v roce 1735 vydal své nejznámější a nejvýznamnější dílo Systema naturae (Soustava přírody). Vědecká fakta a racionalismus tak začaly mít převahu nad dřivějšími mýty a pověstmi. Další zlom v debatě o existenci draků přišel s objevem fosílií pterosaura. První nalezený ptakoještěr byl popsán již $\mathrm{v}$ roce 1784 a tento objev byl následován dalšími, přičemž někteří z nich byli opravdu gigantičtí - například Pteranodon longiceps, kterého objevil a popsal v roce 1876 americký paleontolog Othniel Charles Marsh (1831-1899), měl rozpětí křídel 7 metrů. Ještě více fascinujícím byl nález majestátního Quetzalcoatluse northropi popsaného roku 1975, který mohl dosáhnout rozpětí křídel více jak 12 metrů (někdy je uváděno až 18 metrů). Podobných rozměrů dosahovali i někteří další pterosauři z rodu Hatzegopteryx či Arambourgiania. Další představy o existenci draků ovlivnil v 19. století britský prŕírodovědec Charles Robert Darwin (1809-1882). Právě skrze jeho teorii o přirozeném vzniku a evoluci druhů dostal výzkum draků další dimenzi. Podle této teorie, podpořené objevy vyhynulých druhů dinosaurů a létajících plazů, mohli být živočichové připomínající draky základem pro hledání bájného tvora $\mathrm{v}$ reálném světě. To, že drak mohl kdysi skutečně existovat, se paradoxně mohlo podílet na ztrátě jeho fantastičnosti. Stejně tak je ale na druhé straně patrné mytické povědomí o dracích ve vědě, např́íklad skrze názvosloví. Odkaz draka coby skutečného předka dnešních živočišných druhů by se mohl nalézt u současných obřích hadů či plazů. Snad nejvýraznějším příkladem může být varan komodský (Varanus komodoensis), který bývá nazýván též „komodským drakem“. Také v mnoha mýtech splývali draci s hady, ještěry nebo krokodýly. Aztécký bůh Quetzalcoatl, podle něhož byl pojmenovaný výše zmíněný pterosaurus, měl podobu opeřeného hada. Stejně tak v asijských zemích je drak výrazně podobný hadu bývá zobrazován jako tvor s dlouhým úzkým tělem, který má čtyři tlapy s pařáty a ocas připomínající ploutvi. Ačkoli může létat, křídla mu chybí nebo je má zakrnělá. Zř́ídkakdy však chrlí oheň a je spíše spjatý se živlem vody. V severské mytologii vystupuje mořský had Jörmungandr, který dokázal obtočit celý svět a může nám tedy připomínat bájného uroborose. Jeho motiv se objevuje již u pohřební ikonografie ve starověkém Egyptě (Hornung 2002). Jako uroboros se dále had-drak vyskytuje zejména u gnostiků a ve starých alchymistických textech coby symbol opakujícího se kruhu života. Jeho obraz je někdy doplněn latinskou větou: „Draco interfecit se ipsum, maritat se ipsum, impregnat se ipsum“ („Drak se sám pojídá, sám sebe oplodňuje, sám se sebou se žení“). Přičemž latinské slovo draco, - ónis zde může opět označovat jak draka, tak hada. Uroboros ve své podstatě vyjadřuje věčný koloběh všeho dění, v němž jsou život a smrt, plození a zánik jen stadii nekonečného cyklického pohybu.

$\mathrm{V}$ mnoha západních ${ }^{1}$ mýtech se pak objevuje téma zabití

1 U východoasijských národů se oproti tomu setkáváme s podobou draka, který není symbolem zla, ale naopak dobrých a vznešených vlastnosti. U starých Číňanů byl drak ochráncem rolníků a věřilo se, že má magickou moc přivolat srážky. 
draka. Podle australského anatoma, antropologa a egyptologa Graftona Elliota Smithe (1871-1937) jsou různé pověsti a mýty o „zabití draka“ pokroucenými a neúplnými obrazy primárního mytologického námětu pocházejícího z Egypta. Zde byl drak původně zosobněním životodárné i smrtonosné vodní síly a byl identifikován s bohy a králi. Právě kontrola vody byla základním prvkem draka. Jak ve svém blahodárném, tak destruktivním aspektu byla voda považována za oživeného draka, jehož roli v mytologickém převyprávění převzal Usir (bůh plodnosti a úrody) nebo jeho nepřítel Sutech, ztělesňující ničivé př́rodní síly (Smith 1909, 78). Egyptský „Vodní bůh" (Usir), na jehož plodnosti stálo přežití celé společnosti, odmítl na vrcholu své vitality a moci zemřít a povolal božskou „Velkou Matku“ (Eset), aby jej prostřednictvím nápoje $z$ lidské krve získané při oběti vzkř́isila. Motiv zabití draka může být také zkreslenou interpretací příběhu „zničení lidstva“, který byl v průběhu času mnoha způsoby převyprávěn a rovněž zaměňován s legendou o boji mezi Hórem a Sutechem - zlým drakem (Smith 1909, viii). Touha získat „elixír života“ se tak stala základní hybnou silou, jejímž prostřednictvím povstala materiální i duchovní civilizace. Grafton Elliot Smith pak také jakožto představitel kulturního difuzionismu zdůraznil, že „dračí téma“ není důkazem psychické jednoty lidstva, ale zrodilo se v Egyptě, odkud proniklo do dalších částí světa (viz Budil 2007, 589). Ačkoli zde zmíněné legendy a motivy draka nejsou tak názorně vyjádřeny jako třeba jinde, jsou důkazem evidence daného tématu, bez níž by byl další vývoj podoby draka nesrozumitelný (Smith 1909, 104).

Zejména v období starověku byl drak vnímán jako temný element a jeho zabití, které vykonávali hrdinové, případně samotní bohové, pak bylo považováno za symbol vítězství dobra nad zlem. Tak například v babylonském eposu o stvoření světa Enúma eliš se hovoří o boji akkadského boha Marduka s nestvưrou Tiámatou:

„I střetla se Tiámat a mudřec bohů Marduk, propleteni $v$ zápase, spojeni $v$ bitvě.

Rozprostřel pán svou sit', do té ji chytil, vítr zlý, jenž za ním stál, vypustil proti ní.

Když Tiámat otevřela ústa, aby jej pohltila, vrh do nich vítr zlý, rty nemohla sevřit.

Zuřivé vichry její nitro naplnily,

život se nadmul, ústa široce otevřla.

Vystřelil šíp, rozerval jí břich,

vnitřnosti jeji protal, rozpoltil srdce.

Spoutal ji a její život uhasil,

odhodil mrtvolu a postavil se na ni."

(Epos o stvoření, tab. IV, řádky 93-104)

Ačkoli nikde $\mathrm{v}$ eposu nelze získat přesnou představu o Tiámatině podobě, předpokládá se, že obrazy na pečetních válečcích, které znázorňují boj jakéhosi boha s drakem-hadem, se vztahují právě k boji Marduka s Tiámatou (Hruška et al. 1977, 13).

Řecká mytologie zase vypráví například příběh o obludném stohlavém drakovi Ladónovi, na něhož si netroufal žádný smrtelník. Ladón měl za úkol hlídat zlatá jablka v zahradě Hesperidek. A právě přinést tř̀ zlatá jablka, která střežil Ladón, byl předposlední, jedenáctý úkol krále Eurysthea pro bájného hrdinu Herakla. Ten Ladóna zastřelil šípem ${ }^{2}$ a podle legendy pak bohyně Héra proměnila tělo Ladóna v hvězdný prach, který rozhodila po obloze, čímž vzniklo souhvězdí draka.

V ruských bylinách se zase vypráví o hrdinském činu bohatýra Dobryni Nikitiče z Kyjeva, který svou odvahou přemohl draka Gorynyče: „Dobryňa bil se ještě tři hodiny se saní a přemohl saň proklatou. Krev se $z$ ní proudem valila a saň se v ní zalkla. I stál u ní Dobryňa po tř́ dny a po tři noci a nemohl se dočkati, až všecka krev ze saně vyteče " (Byliny: Staré ruské bohatýrské písně 1925, 49).

Ve stř̌edověku bylo téma zabití draka ještě častější a takový čin byl vždy hodnocen velmi kladně. V křestanství byl atributem svatých, např́klad svaté Marty, svatého Gotharda, svatého Jiří či svaté Markéty Antiochijské, s významem víry, která má zkrotit nevěrectví. Drak je v této souvislosti považován za zlého ducha, nepř́tele lidstva a jeho zabitím je také vyzdviženo přemožení původního pohanství. Drak-had se objevuje rovněž na vyobrazení Immaculaty neboli neposkvrněného početí Panny Marie. V ikonografické podobě Immaculaty stojí Marie jako mladá dívka se sepjatýma rukama na půlměsíci, který je obtočen hadem či drakem symbolizujícím překonání prvního hříchu. Je zde rovněž nepochybná souvislost $s$ biblickým veršem: „I řekl Hospodin hadovi: „...mezi tebe a ženu položím neprátelství, i mezi símě tvé a símě její. Ono ti rozdrtí hlavu a ty jemu rozdrtís patu“(Gn 3,15). I např́iklad samotné jméno Panny Marie Guadalupské je možné odvodit z aztéckého slova „Coatlaxôpeuh“, které znamená „rozšlápla jsem draka-hada“, což je přemožený pohanský bůh Quetzalcoatl.

Příkladů boje hrdiny s drakem bychom mohli uvést nesčetně. $\mathrm{V}$ českém prostředí je drak spjatý zejména s městem Trutnov. Pověst o trutnovském drakovi je zasazena do období vlády knížete Oldřicha. Ten údajně poslal do pohraničních hvozdů svého vazala, pana Albrechta z Trautenbergu, aby zde založil nové město. Při budování města však v divoké rokli objeví obrovského plaza s široce otevřenou tlamou a tělem pokrytým velkými rohovitými šupinami. Drak byl zabit a jeho kůže vysušena a vystavěna všem $\mathrm{k}$ obdivu. Když pak kníže Oldřich pořádal 1. května roku 1024 zemský sněm v Brně, na němž svému synu Břetislavovi svěřil vládu nad Moravou, přišli mu popřát i trutnovští a jako dar předali svému knížeti draka. Ten jej přijal a nechal zavěsit $\mathrm{v}$ brněnské radnici. Avšak onen drak, který je dodnes zavěšen u vchodu radnice, není nic jiného, než vycpaný krokodýl. Pokud nahlédneme do českých pohádkových knížek, nelze opomenout klasickou pohádku od Boženy Němcové Princ Bajaja či Draka dvanáctihlavého od Karla Jaromíra Erbena nebo nejnověji v knížce antropologa Jaroslava Maliny Mluvící prahrnec a jiné prapříběhy (2012). Roli epického draka lze interpretovat několika způsoby. V souvislosti s křestanstvím byl drak vnímán jako ne-

2 Podle jiné verze tohoto mýtu si však na děsivého Ladóna netroufl ani Heraklés (viz Zamarovský 2005, 241). 
čisté démonické stvoření a symbol pohanství. Jeho zabití pak bylo vnímáno jako potlačení starých náboženství. V pohádkách ničemný drak zabíjí a pojídá lidi i zvířata, sežehává trávu a obilí, způsobuje sucho a zejména unáší, požaduje nebo svádí ženy, které se mají stát jeho potravou nebo milenkou (Warner 2006, 70). Hlavním hybatelem jsou námluvy, kdy má hrdina zachránit unesenou ženu a tu následně pojmout za svou manželku (Warner 2006, 71).

Podle amerického religionisty Josepha Campbella (19041987) je hrdina „člověk, kterému se podařilo probojovat přes svá osobni a místní historická omezení ve prospěch všeobecně platných lidských forem" (Campbell 2000b, 33). Hrdinovo dobrodružství se pak ubírá dráhou, jež opisuje vzorec představovaný přechodovými rituály, tedy: odloučení - iniciace - návrat. Tento vzorec lze označit za základní jednotku monomýtu. „Hrdina se vydává z každodenního světa do ř́iše nadprirozených divů, setkává se tam s úžasnými silami a dosahuje přesvědčivých vitězství. Ze svých tajuplných a dobrodužných cest se vrací se schopností prokazovat dobrodiní svým blizkým" (Campbell 2000b, 41). Až hrdinská výprava dospěje ke konci, je pak třeba, aby se hrdina vrátil zpátky se svou život proměnuující trofejí „poněvadž pravidla monomýtu vyžadují uzavřený kruh - hrdina nyní musí prinést runy moudrosti, zlaté rouno nebo spící princeznu zpět do království lidí, kde jeho dobrodiní může př̀ispět $k$ obnově společenství, národa, planety nebo deset $i$ tisíc světü“ (Campbell 2000b, 179).

\section{HRDINOVÉ A DRACI VE SVĚTĚ FANTASY}

Jak již bylo řečeno výše, drak v současné době ožívá zejména díky žánru fantasy. A dalo by se říci, že se přímo přemnožil. Došlo zde však $\mathrm{k}$ porušení klasických pravidel rozlišování toho, co drak může, jaké má schopnosti a atributy. Kromě klasických draků, kteří chrlí oheň, se dnes mohou hrdinové setkat s draky ledovými či draky chrlícími kyselinu nebo jedovaté plyny. Obzvlášt nebezpeční jsou draci bleskometní ...

Snad nejznámějším fantasy drakem, kterého znají i lidé, kteří nečetli Tolkienův román The Hobbit, or There and Back Again (Hobit aneb Cesta tam a zase zpátky, 1937), je drak Šmak Zlatý. Draci vystupující v Tolkienově díle kradou zlato a šperky lidem, elfům i trpaslíkům. Nahromaděnou kořist pak hlídají, dokud jsou naživu - což znamená prakticky věčně, pokud je někdo nezabije. Obzvláště hrabivý silný a zlý drak byl výše zmíněný Šmak. Posedlý svým pokladem trávil většinu času uvnitř Osamělé hory, kde na něm spal a hlídal ho. Tak ho spatřil i hobit Bilbo Pytlík: „Šmak s kř́idly rozloženými jako gigantický netopýr ležel částečně přvalený na bok, takže hobit viděl spodek jeho těla a bledé bricho s pancírem drahokamů a úlomků zlata, které mu zarostly do těla od dlouhého ležení na tom drahocenném loži“ (Tolkien 2005, 153). Když musel Šmak opustit svou skrýš, aby se najedl, činil to tajně, aby se o jeho odchodu z hory nikdo nedozvěděl a nemohl se tak zmocnit pokladu.

V klasické epické fantasy bývají draci vnímáni jako moudří tvorové, s tisíciletou zkušeností, mnohdy inteligentnější než lidé. Ovládají magii, at’ už ve své přirozené formě nebo v podo- bě naučených zaklínadel, patří mezi nejnebezpečnější protivníky, ke kterým hrdinové př́iběhu směřují. $V$ extrémních př́ipadech se však stávají bezduchými vraždícími monstry, jako je tomu např́klad ve filmu Reign of Fire (Království ohně, 2002). Draci také nemusejí být nutně zlí. Setkáváme se $s$ př́běhy, ve kterých jsou vnímáni jako tvorové přátelští či slouží jako jezdecká zvířata, například v teenagerské fantasy trilogii amerického spisovatele Christophera Paoliniho (narozen 1983) Inheritance Cycle (Odkaz dračích jezdcu, 2002; 2005; 2008). Někteří draci mohou na sebe také brát lidskou podobu, jako je tomu u postavy Borcha, zvaného také Tři kavky v povídce polského spisovatele Andrzeje Sapkowského (narozen 1948) Granica możliwości (Hranice možností, 1992). Jeho proměna z člověka na draka je popsaná následujícími slovy: „To nebyla stupňovitá, rozmazaná promèna, ani mlhavé chvění doprovázející přeludy. Bylo to bleskové, rychlejší než mrknutí oka. $\mathrm{Na}$ místě, kde ještě nyní stál kučeravý rytír v tunice s třemi černými ptáky, sedèl mohutný zlatý drak. Sklonil před nimi hlavu na dlouhé šiji a rozepjal zlatá kř́dla oslnivě se třpytící v paprscích slunce" (Sapkowski 2008, 71).

V současné beletristické literatuře a moderním filmu se velice často opakuje prríkladný vzor boje hlavního hrdiny se zločincem (ztělesněním zla), objevují se zde motivy pronásledované dívky i spásonosné lásky apod. (Eliade 1998, 23). Nejpatrnější je to však právě ve zmíněném žánru fantasy, kdy zkoušky, jimiž musí hrdina $z$ fantasy románu či hry projít, připomínají zkoušky mytického hrdiny. Objevuje se zde klasický boj dobra se zlem, kladného dobrodruha se záporným zlosynem. Podle švýcarského zakladatele analytické psychologie Carla Gustava Junga (1875-1961) jsme v tomto smyslu ovlivněni kolektivním obrazem lidské psychiky, který nám ř́ká, že všichni ti fantazijní tvorové, bájná zviŕata, se kterými se setkáváme v mýtech, pověstech, pohádkách nejsou ničím jiným než projekcí nevědomých obsahů neboli archetypy, které mají lidé tendence hledat ve svém životě. „Není novým objevem, že archetypické obrazy jsou projikovány. Skutečně musí být projikovány, jinak by zaplavily nevědomi“" (Jung 1997, 165). Se vstupem do světa fantasy tedy zároveň vstupujeme do světa mytologie a hledáme něco, co se může stát vzorem hodným následování a co může napomoct k nalezení smyslu situací, se kterými se setkáváme v reálném světě (viz Mádrová 2004, 15).

Podle Josepha Campbella se hrdinou v dnešní době může stát každý: „Není to společnost, $k$ do vede a zachrání tvořivého hrdinu - je to právě naopak. Tak tedy každý z nás nese svůj díl nejvyšší zkoušky a vykupitelưv křiž - nikoli v rozzářených okamžicích velkých vítězství svého kmene, ale v tichu své osobní beznaděje“ (Campbell 2000b, 339). O tom vypráví řada současných filmů i knižních románů. O tom jsou i takzvané „hry na hrdiny“.

\section{HRY NA HRDINY (RPG)}

„V Dungeons \& Dragons se mưžete snadno stát mocným bojovníkem, chrabrým paladinem či běsnícím barbarem; můžete okusit magickou moc v podobě čarodèje nebo kouzelníka či vykonávat vưli boží jako kněz, př́padně vưli samé matky přiro- 
dy v podobě druida. Můžete se vtělit do prostého tuláka, muže mnoha profesí, nebo se proslavit jako bard. Konečně, můžete se postavit i divočině $v$ podobě hraničáre či ovládnout své vlastní nitro jako mnich. $V$ této hře však před vámi neleží jen volba povoláni a rasy, zda být statným trpaslikem, sličným elfem či radèji mrštným pulč́kem, mazaným gnómem nebo hrưzu nahánějicím pưlorkem. Nebo zůstat nakonec přeci jen člověkem se všemi jeho skrytými talenty. Největši volba, jež před vámi leží, je volba vaší budoucnosti. Jak se zachovat a kam se vrtnout $v$ tisících různých světù, svètù, jež nemaji jiné hranice než hranice vaši fantazie ..." (Co je to Dungeons \& Dragons?, Zdroj: icaenel.d20.cz).

Hry na hrdiny neboli RPG (Role Playing Games) jsou úzce propojeny fantasy literaturou ${ }^{3}$. Vycházejí z principu, že hráč si v jejím průběhu vytvárí postavu, své imaginární „já“. Tímto způsobem je mu umožněno přijmout cizí identitu, vyjít z reality běžného světa do jiného, lepšího. Hráč se může oprostit od norem a nárokủ své běžné životní role a vrhnout se do adrenalinového dobrodružství, aniž by mu hrozilo nějaké reálné nebezpečí. Může se stát udatným rytî́̌em i zlým čarodějem. Otevírá se mu možnost ventilovat v reálném životě neuskutečnitelné způsoby chování, hrát roli odlišnou od běžného chování, a to dokonce roli s reálným životem neslučitelnou (Holý 2004, 20). Většina takovýchto her je zasazena do světa zdánlivě připomínajícího středověk (i když rozmanitost herních prostředí je stále bohatší) ovlivněný mýty a legendami a hráč se zde může setkat s tajuplnými hrady, udatnými rytíři, děsivými draky a dalšími bytostmi. Jejich tématem je motiv dobrodružství, akčních činů, vydávání se na místa hrůzy a strachu, př́ípadně je vše okořeněno prvky komiky a humoru. Naopak milostné príběhy, emoce a erotika se v nich vyskytují minimálně (Holý 2004, 38). Dalo by se říci, že hry na hrdiny jsou formalizovanou narativní aktivitou postmoderní doby. Nad dějem a prostředím hry bdí inteligentní „yyšší bytost" $\mathrm{v}$ podobě Vypravěče či počítače. Kontroluje charaktery a činy jednotlivých postav, rozhoduje, jaké následky bude mít jejich jednání. U stolních RPG her si zápletku př́běhu Vypravěč obvykle připraví předem, ale mnohdy se během samotné hry děj rozvine zcela improvizovaně a nečekaně. Jisté ale je, že hrdinové se budou střetávat s nadpřirozenými protivníky, budou plnit nadlidské úkoly, prokazovat výjimečně schopnosti. Během hry hráči popisují rozhodnutí a činnosti svých postav, komunikují s ostatními postavami a také používají kostky, na základě nichž jim Vypravěč sdělí, zda jejich hrdina ve svém činu uspěl či ne. Hra probíhá pouze ve fantazii zúčastněných, nikdo nikam neodchází - hráči pouze ostatním popisují, co se zrovna v paralelním světě děje.

Rozmach her na hrdiny v Čechách nastal počátkem devadesátých let, kdy nakladatelství Altar vydalo první hru tohoto druhu s názvem Dračí doupě (1990), která byla zřejmě inspirovaná americkou hrou Advance Dungeonsè Dragons, jež byla poprvé vydána roku 1974. Název této hry vychází z toho, že

3 Zdrojem tématiky her na hrdiny ale není pouze fantasy literatura, některé $\mathrm{z}$ nich čerpají například z komerční filmové produkce, hororové či sci-fi literatury. hrdinové procházeli kobkami (dungeons), kde bojovali s draky a různými nestvůrami (dragons) ${ }^{4}$. Po americkém vzoru se pak následně i v Čechách začala pořádat setkání hráčů neboli „GameCony“ či „larpy“ (hry na hrdiny naživo)

Virtuální světy her na hrdiny mají určitý př́měs nereálných, abstraktních a ryze fantazijně/fiktivních prvků; velkou roli zde hraje nereálný způsob zacházení s realitou. Tímto způsobem se naruší zavedená logika skutečného světa a vytvář́i se pocit tajemnosti a lákavosti neprozkoumaného. Technologie, které jsou zcela jiné povahy, než ty, se kterými se setkáváme v běžném životě, at už v podobě magie nebo vyspělé vědy, zvyšují atraktivitu těchto her (Janeček 2002, 110). Vedle toho se zde objevuje ostře vyhraněný etický rozměr. Chování a morálka postav je většinou velice zjednodušovaná a základní idejí je boj dobra se zlem. Hrdinové těchto her by měli být schopni stát mimo svůj vlastní svět, nebrat si s sebou problémy a zažít pocit, že zde není nic, co by je omezovalo (Janeček 2002, 112). Je třeba si uvědomit, že „to znamená se od tohoto světa odpoutat, nechat zde v̌se, co odtud pochází a otevř́t se světu tam. Tak jako každý prechod, i tento je zvláštní a zahrnuje v sobě zkoušku pro poutníky mezi oběma světy. Ten, kdo neodloží zdejší šat, se může jen těžko ošatit světem tamním - a vše, co zde neponechal, mu bude prítěžżi. To samé ale platí i př̀ návratu - kdo nedokáže sundat šat světa tam, zdejším světem se mu bude chodit jen těžko"(Krajhanzl 2001, 37).

Petr Kamberský se na svět RPG her dívá jako na svět mýtu a archaického nahlížení, kde hráči hledají obranu před realitou postmoderní společnosti, poněvadž hraní svým obrácením $\mathrm{k}$ bytostně zakoušenému vyprávění, $\mathrm{k}$ tradičnímu světu, je nejvýraznější odpovědí na „neřád dnešní doby“" (Kamberský 1994, 12).

Kdo jsou lidé, které hraní her na hrdiny oslovuje? Věková hranice hráčủ her na hrdiny se obvykle pohybuje v rozmezí 17 a 25 lety. Ve výzkumu, který prováděl Petr Janeček, je patrné, že mezi hráči her na hrdiny jsou zejména studenti vysokých škol (jak technického, tak humanitního typu) nebo zaměstnanci (přičemž poměrně velké množství $\mathrm{z}$ nich pracuje $\mathrm{v}$ ob-

4 Hysterie kolem této hry vyústila $\mathrm{v}$ řadu soudních procesů, kdy byl její vydavatel obviňován ze sebevraždy mladých lidí, kteří tuto hru hráli. Svět hry se pro ně jevil jako skutečnější než svět reálný a smrt herní postavy vnímali tak fatálně, že pozbyli smyslu dalšího života (Vágner 1995).

5 „Con“ (z anglického convention) je označení pro setkání/festival fanoušků sci-fi, fantasy i jiných žánrů. Con bývá zpravidla vícedenní akcí $s$ alespoň částečně předem připraveným programem. Nejstarším českým conem, pořádaným od roku 1995, je právě GameCon, který je zaměřený převážně na RPG, moderní deskové a karetní společenské hry. „Larp“ je akronymem anglického spojení „live action role playing“. Je formou hraní rolí, kde se lidé reálnými činy snaží splnit cíle, které jsou jim určeny ve fiktivním světě. Český larp se začal vyvíjet během 90 . let minulého století. První larpy byly zpočátku jen živým ztvárněním tehdejších her na hrdiny, postupně pak získávaly na oblibě tzv. městské larpy, které cíleně využívají městského prostředí a často se prolínají s reálným životem hráče. Larpy rovněž mohou obsahovat i jiné herní prvky, jako je řešení hádanek či simulovaný boj s umělými zbraněmi. 
lasti informačních technologií), což podle autora narušuje zažitý stereotyp, že tyto hry jsou převážně studentskou zábavou (Janeček 2002, 53). Vedle her na hrdiny se objevuje u hráčů zájem o počítačové hry obecně. Více než třetina hráčů jako svůj motiv ke hře uvedla fascinaci virtuálním herním světem. Líbí se jim jeho detailní propracovanost a zároveň podobnost literárním fiktivním světům a každodenní realitě zároveň (Janeček 2002, 58). Je zde zjevná touha hledat magické ve světě, který je pohlcen informačními technologiemi, a alespoň ve hře si připadat jako rytír a udatný válečník.

Britští psychologové Neil A. Douse a Ian Chris McManus se ve studii The Personality of Fantasy Game Players (Osobnost hráčů fantasy her) zaměřili na hráče modernější verze her na hrdiny, tzv. Play-By-Mail, která probíhá, jak už název napovídá, prostřednictvím e-mailové komunikace. Na základě empirického šetření pak došli k závěru, že „většina hráču jsou muži s nevýraznými sexuálními rolemi, kteři vykazovali nižši stupeň empatie s ostatními, často popisovali sami sebe jako,vědeckého zaměrení a mezi své oblibené koníčky zařazovali nejčastěji , hraní na počítači $a$,čteni"“ (Douse - McManus 1993, 505).

Výzkumy prováděné na téma hráčů her na hrdiny zároveň ukázaly, že o tyto hry má zájem jen minimum žen a jsou doménou zejména mužů (Holý 2004, Janeček 2002, Krajhanzl 2001, Leppälahti 2003). Opravdu však žijí fantastické bytosti pouze v mužském světě? V klasických RPG hrách a epických fantasy žánrech jsou ženské role mnohdy druhořadé (pokud v nich mimo bojování nejde o lidské vztahy a řešení problémů, což se tř̌eba děje v larpu), a tak není divu, že ženy př́líš neoslovují (Leppälahti 2003,4). Nicméně v jiné rovině ženy do fantastického světa vstupují. Podíváme se blíže na upíry a jejich oběti ...

\section{CO MŮŽE BÝT NEBEZPEČNĚJŠÍHO NEŽ SE ZAMILOVAT DO UPÍRA?}

„Budu vám vyprávět príběhy o Anitě a světě, kde jsou upiři, zombie a vlkodlaci skutečnými občany Spojených států. Budu vám vyprávět o lásce a cti, nenávisti a odplatě, o životě a smrti, a také o smíchu, protože policisté a záchranáři dokážou vyprávět ty nejzábavnější historky (...). Budu vám vyprávět příběhy o nocích, které probudily skutečné, živoucí a hladovějící. Budu vám vyprávět př́běhy, $v$ nichž při honbě za spravedlností zemřelo tolik lidí, že vás to začne pronásledovat ve snech"

( $\mathrm{Z}$ internetového blogu Laurell K. Hamiltonové, Zdroj: Bordesblog.com).

Upírí byli ve starých mýtech a lidových vyprávění bytostmi děsivými, se kterými není radno se potkat. Strach z upírů nabíral na intenzitě zejména, když došlo k rozšíření nakažlivých chorob, o jejichž původu se v dřívější době př́iliš nevědělo. Věřilo se, že nemoc, která ohrožuje ostatní, je vinou nedávno zemřelého, který se stále vrací, aby uškodil na zdraví, životě či majetku ostatním. Mnohdy se v této souvislosti zmiňuje porfyrie, mezi jejíž příznaky patří například přecitlivělost kůže na světlo, zčervenání zubů či ústup dásní, který vytvářel dojem tzv. upírích zubů. Toto onemocnění však bylo příliš vzácné, než aby se mohlo stát základem upírského mýtu. Upírem se mohl stát kdokoli: mohl to být sebevrah, člověk, který zemřel násilnou smrtí nebo se nějakým způsobem psychicky či fyzicky odlišoval od ostatních. V př́ípadě, že bylo toto podezření, přistoupilo se k otevření hrobu podezřelého, kde bylo většinou nalezeno ještě nerozložené mrtvé tělo. Díky rozkladným plynům působil povrch odkrytých částí jako regenerovaná pokožka a prázdná nehtová lůžka se zdála připravená pro růst nových nehtů. Rozkladné plyny byly u mužů také příčinou erektovaného (nafouklého) penisu. To vše mohlo být vnímáno jako důkaz, že zemřelý byl upír. Mnohdy citovaným prŕkladem této analogie je příběh Petra Plogojowitze, který se odehrál roku 1725 v Srbsku. Plogowitz začal po několika týdnech od své smrti navštěvovat svou ženu. Během devíti dní napadl ve spánku dalších devět mužů a několik žen - padl na ně v posteli, rdousil je a slastně jim vysával krev z těla. Všechny oběti pak do jednoho dne zemřely. Panika, která se začala šírit, si vyžádala otevření hrobu a spálení těla. Úkolem byl pověřen rakouský státní lékárník, který při exhumaci zaznamenal stav zesnulého, jehož mrtvola nejevila žádné známky rozkladu, nebyl cítit žádný zápach. Tělo, s výjimkou nosu, bylo zcela svěží. Vlasy, vousy i nehty mu znovu vyrostly, stará kủže bělavé až popelavé barvy ustupovala nové a svěží kůži. Celé tělo nebožtíka se nacházelo v lepším stavu než za jeho života. Na rtech měl stopy čerstvé krve, kterou podle obecného mínění vysál z osob, jež zabil (Maiello 2004, 26).

Podobně jako u draků lze upírí odkaz hledat v živočišné říši. Z tohoto hlediska upíri skutečně existují, jedná se však o malé netopýry (dosahující až deseti centimetrů délky), kteří se živí krví zvířat a nalezneme je v oblastech Jižní Ameriky a karibských ostrovů. Mají méně zubů než ostatní netopýři, ale jsou mezi nimi dobře patrné velké a ostré řezáky, díky kterým dokážou proniknout kủží savců a $\mathrm{z}$ vytvořené rány sát krev. Jejich obětmi se stává hlavně dobytek, ale i koně a ve výjimečných př́ípadech i lidé. Není pravděpodobné, že by se Evropané mohli s těmito zviŕraty setkat dříve než $\mathrm{v} 16$. století, v latinskoamerických zemích se však existence těchto tvorů do mytologie promítla. Z obavy, že tato zvírata sají lidskou krev, vycházelo mystické spojení netopýrů a upírů s obětováním a také stínáním lidských hlav. Představu obludného netopýŕího zabijáka jménem Camazotz velmi působivě líčí kniha o mayské mytologii Popol Vuh. V klasickém mayském období se na malované keramice objevují netopýrí bytosti s atributy značící smrt, jakými jsou oční bulvy nebo zkřížené hnáty. Camazotz, který je pokládán za služebníka smrti a vládce noci, představuje pro Maye hrozného boha jeskyň, bažícího po krvi a lidé se vyhýbali místům, o kterých se domnívali, že jsou domovem Camazotze. Mnoho archeologů se domnívá, že původ této stvůry je založen na typickém představiteli rodu upírovitých Desmodus rotundu, který je tradičně spojován s krvežíznivectvím a obětmi. Jiní tvrdí, že by inspirátorem legendy mohl být, díky své obrovské velikosti, rozpětí křídel až 60 centimetrů a zvyku útočit na kořist $\mathrm{v}$ oblasti hlavy nebo krku, falešný vampýr Vampyrum spektrum. V některých oblastech Latinské Ameriky přetrvává víra v „netopýra smrti“ dodnes. Např́iklad legendy o Hik’al neboli „Černém muži“ stále kolu- 
jí mezi lidmi v Chiapasu. Někdy se o Hik’alovi zmiňuje jako o „stínači hrdel“. „Černý muž“ je také často obviňován, že unáši ženy a požírá je uvnitř jeskyně, ve které žije.

V souvislosti s upíry je mnohdy zmiňovaná také jejich sexualita. Již dávný hebrejský mýtus hovoří o Lilith, která údajně byla první ženou Adama. Ten očekával, že mu bude podřízena, Lilith to však odmítla a po závěrečném konfliktu utekla do pustin poblíž Rudého moře, kde se sblížila s démony zla a stala se matkou démonických dětí. Lilithina pomsta nezůstala bez potrestání. Byla pronásledována božími posly a její děti byly vražděny. $\mathrm{V}$ reakci na to se Lilith začala mužům mstít tím způsobem, že je v noci navštěvovala a vysávala jim veškerou životní sílu. Stala se sukubou.

Právě se zdůrazněním erotiky, sexuality, smyslnosti a zakázané lásky se v 19. století rozvíjela postava romantického upíra. Tradiční podoba folklorního upíra byla transformována do moderní podoby v povídce britského spisovatele a osobního lékaře Lorda Byrona Johna Williama Polidoriho (17951821) The Vampyre: A Tale (Upír, 1819). Polidori zde upíra popisuje jako šlechtice, jehož zrak dokázal při pohledu do očí druhého proniknout až do jeho duše. Jeho mrtvolně bledý obličej, ač svým tvarem a rysy velmi krásný, nikdy nenabyl vřelejšího výrazu, nikdy se nezarděl hanbou ani návalem vášně. Přesto (anebo právě proto) vyvolával u žen touhu upoutat jeho pozornost a probudit v něm jakýkoli náznak náklonnosti. Tato etapa pak vyvrcholila v roce 1897 zrodem slavného hraběte Draculy na stránkách románu britského hororového spisovatele Brama Stokera (1847-1912). Hrabě Dracula, ač na první pohled postava velice děsivá, vyvolávala u čtenářu (a zejména u čtenářek) vzrušení a přitažlivost. Př́ikladem hororové erotiky Stokera nám může být následující ukázka: „Měsíc svítil tak jasně, že přes hustou žlutou záclonu bylo v pokoji dost světla, aby bylo dobře vidèt. Na loži u okna ležel Jonathan Harker, tvár mél zrudlou a těžce oddychoval, jako by byl omámen. U pelesti vzdálenější postele klečela bíle odèná postava jeho ženy. Vedle ní stál vysoký hubený muž v černých šatech. Obličej měl od nás odvrácen, jenže sotva jsme ho spatřili, hned jsme ho poznali byl to hrabě, jeho postoj i ta jizva na čele! Levou pèstí svíral paní Harkerové obě ruce a napjaté paže jí odtahoval od těla; pravou rukou jí pridržoval hlavu v týle a tiskl si její obličej k hrudi. Její bílá noční košile byla potřísnèna krví a po Draculově obnažené hrudi, vystupující z rozhalené košile, stékala tenká stružka krve. Postoj těch dvou hrůzně pripomínal obrázek dítěte, které strká kotěti čumáček do misky s mlékem a nutí je pit. V okamžiku, kdy jsme vrazili do pokoje, hrabě se obrátil a jako bleskem se mu na tváŕi rozhostil onen d'ábelský výraz, o němž jsem už slyšel. Oči mu rudě vzplály přišserným vztekem, široké nozdry bílého orlího nosu se rozšírily a rozechvěly a ostré bílé zuby pod širokými rty zbrocenými krví se prudce sevřely jako zuby šelmy. Divoce odhodil svou obět' na postel, kam dopadla jako $z$ výšky, obrátil se a vrhl se na nás" (Stoker 1970, 281). Britská literární vědkyně Carol A. Senfová se v článku Dracula - Stoker's Response to the New Woman (Dracula - Stokerova reakce na novou ženu) zmiňuje o dvou typech ženství, které Stoker ve svém románu vykresluje. První část románu se soustředí na nevinnou a cudnou Lucy Westenrovou, která je proměněna $\mathrm{v}$ agresivní a smyslnou upírku a musí být následně násilně zabita. $\mathrm{V}$ druhé části knihy popisuje Stoker Minu Murrayovou jako ženu, která je protikladem destruktivních monster. Mina nejenže uniká osudu ostatních žen, ale je také odpovědná za dopadení a konečnou zkázu Draculy (Senf 1982, 34). Byla tedy podle Senfové prototypem nové moderní nezávislé a inteligentní ženy, která se emancipovala na přelomu 19. a 20. století. Lucy je věčným dítětem, které je hýčkané svým okolím, oproti tomu Mina se umí postarat sama o sebe, pracuje jako pomocná učitelka (je tedy ekonomicky nezávislá) a je produktivním a suverénním členem společnosti (Senf 1982, 45). Zároveň si však v sobě Mina zachovává ty nejlepší prvky tradičního pojetí ženství, což je nejvýstižněji popsáno postavou holandského lékaře Van Helsinga: „Je jednou $z$ žen stvořených rukou boha, aby nám mužưm i jiným ženám ukázal, že je nebe, do něhož můžeme vejíti a jehož světlo zárú jižz zde na zemi. Je tak věrná, tak sladká, tak ušlechtilá, tak nesobecká - a to je v tomto tak skeptickém a sobeckém věku něco vskutku výjimečného" (Stoker 1970, 188).

Draculovy oběti byly vždy ženy, vztah mezi upírem a obětí však nemusel být nutně heterosexuální, důležitá byla zejména jeho vášnivost. Ještě před Stokerovým Draculou, v roce 1872, vyšla kontroverzní gotická novela irského spisovatele Josepha Sheridana Le Fanu (1814-1873), která vypráví příběh mladé ženy, jež si vytvořila silné přátelské i sexuální pouto s upírkou Carmillou. V Carmille hlavní hrdinka Laura popisuje upírku jako nádhernou ženu vyšší postavy, štíhlou a neobyčejně půvabnou, s hebkou, nádhernou pletí, drobným a krásným obličejem, s hustými tmavohnědými a neuvěřitelně jemnými vlasy (Le Fanu 2010, 28). Erotický vztah mezi dívkami je v knize naznačen například $\mathrm{v}$ následující scéně: „Někdy mě po hodinách apaticky prosezených $v$ kresle má zvláštní a nádherná př́telkyně chytila za ruku a s láskou ji stiskla. Znova a znova. Mírně se červenajíc mi roztouženýma a lesklýma očima hleděla do tváre a dýchala tak prudce, až se její šaty viditelně zvedaly a klesaly. Připomínalo to vášeň milence a přivádělo mě to do velkých rozpaki. Bylo to odporné, ale navzdory smišeným pocitům mě to pokaždé přmohlo. S planoucím pohledem si mě pritáhla blíž a horkými rty mi tvář zasypávala polibky. Přitom šeptala plačtivým hlasem, Jsi moje, budeš moje. Ty a já jsme jedna bytost a tak to bude navěky“" (Le Fanu 2010, 31).

Obrovský zájem o upírskou tématiku narůstal v průběhu 20. století s jejím vstupem na filmová plátna či prkna divadel a upíri zůstávají atraktivním motivem dodnes. Stejně jako $\mathrm{u}$ draků, je patrná velká rozmanitost v podobě i povaze upírů a posun $v$ jejich stereotypizaci.

Typickým příkladem přepracování starých upírských vzorů je série The Vampires Chronicles (Upírí kroniky), která vycházela mezi lety 1976 - 2003, americké spisovatelky Anny Riceové (narozena 1941). Na upíry, o kterých píše Riceová, neplatí klišé, jež byla spojena s upírem Draculovského typu - tedy svěcená voda, ochrana česnekem ani dřevěný kůl; v zrcadle se odrážejí stejně jako obyčejní smrtelníci. Naopak jsou více naladěni na atmosféru současné doby. Jak píše americký literární vědec Martin J. Wood ve studii New Life for an Old Tradition: Anne Rice and Vampire Literature (Ožívání staré tradice: 
Anna Riceová a upírská literatura): „Tak jako před ní Stoker, zmènila Riceová kód. Napadla tradiční podobu upírů několika zásadními způsoby, které nemohou být náležitě pochopeny, pokud jsou čteny způsobem odpovídajícím starým prostředkům" (Wood 1999, 60). V souladu s tímto novým kódem mohou být upíri viděni jako úžasnější a jemněji vyvinutí lidé (Wood 1999, 67). Riceová zde předkládá koncepci, ve které upíri nejsou postavami zápornými, nýbrž ukazuje, že opravdové zlo spočívá v lidech samotných. Ideje starých mýtů, folkloru se zde mísí s moderními pocity odcizení, neidentifikování se s životem majoritní společnosti. V upírech nadále zůstávají lidské emoce, tak jak to naprríklad vyjadřuje postava Louise v nejznámější knize ze série Interview with the Vampire (Interview s upírem, 1976): „Cítil jsem se ztrápený a zmatený jako kterýkoli smrtelný člověk. Zavřel jsem na chvíli oči a snažil se vypudit z hlavy všechny myšlenky. Jen poslouchat a divat se, říkal jsem si“ (Rice 1996, 110). K př́iblížení upíra současné společnosti Riceová přispěla také tím, že svůj příběh lokalizovala do městského života oproti dřívější tendenci vyzdvihovat v upírských vyprávěních odlehlost až naprostou izolaci, tmu, rozklad a smrt, tedy ve starých sídlech, hřbitovech a kryptách. V tom ale spočívá i určitá záludnost - z vyprávění odehrávajících se ve vzdálených a nepřístupných místech se dalo snadno odejít, přestěhováním upírů do měst se bariéra zmenšuje. Další tématikou, kterou pak Riceová podle Wooda posunula, je sexualita upírů. Ti sex díky chybějícím reprodukčním orgánům jako takový mít nemohou, ale jejich postavy jsou stále zobrazovány jako vášnivé a plné sex-appealu. „A já jsem pil, sál jsem jeho krev a poprvé od raného détství jsem zakoušel onu zvláštní rozkoš, tělem i myslí zaměren na životní zdroj ... Když jsem sál krev, neviděl jsem nic než to světlo"(Rice 1996, 18-19). Erotický prvek zde představuje zejména zabíjení a sání krve (pro upíry tělesná láska vrcholí a je naplněna jedinou věcí zabitím), přičemž se nezaměřují pouze na tělo, ale i na prožití blízkosti a intimity bez ohledu na gender (a věk) toho druhého. Na základě tohoto kódu, jak píše Wood, lze smyslně popsané setkání mezi lidským mužem a mužem upírem nebo dvěma upírskými muži vnímat ne jako evidenci homosexuality, ale jako sex bez genderu (Wood 1999, 75).

Další americkou spisovatelkou, která se zasadila o transformaci upíra a jeho oběti, byla $\mathrm{v}$ devadesátých letech Laurell $\mathrm{K}$. Hamiltonová (narozena 1963). Ta přináśí postavu Anity Blakeové - lovkyně upírů. Série knih s Anitou Blakeovou v hlavní roli se odehrává ve fiktivním fantasy světě, ne nepodobném našemu, kde vedle obyčejných lidí žijí také upiŕi, vlkodlaci a jiné nadpřirozené bytosti. Vedlejší zaměstnání oživovatelky Anity Blakeové je právě lov a exekuce odsouzených upírů. První knihy Hamiltonové kladou důraz na distanc hlavní hrdinky od jakéhokoli bližšího vztahu s nadpřirozenými bytostmi, ale klasické téma erotiky, charakteristické pro romány s upíry v předchozích dekádách, se v novějších dílech objevuje a graduje vztahovými peripetiemi, které prožívá s upírím Vládcem města Jean-Claudem a vlčím alfa samcem Richardem. Přese všechno má Anita představovat silnou hrdinku, která je obětí jedině svých vlastních slabostí. Tento postoj neohroženosti a emancipace vyjadřuje například následující rozhovor s vlkodlakem Richardem z desátého dílu série: Richard: „Proč musiš být nejtvrdší, nejstatečnějšš? Proč mi nemůžeš, aspoň jednou, dovolit, abych pro tebe něco udělal?" Anita: „Protože mě to děsí a musím zjistit, jestli to dokážu." Richard: „Proč? Proč se to musíš dozvědět? Dokázalas mně a všem tady, že jsi tvrdá. Nemáš nám už co dokazovat." Anita: „Sobě, Richarde, mám co dokazovat sama sobě“ (Hamilton 2001, 235).

Podobně jako napríklad hrdinka filmu Buffy the Vampire Slayer („Buffy, přemožitelka upírü“; česky jako Buffy, zabiječka upírů) z roku 1992 (navazující seriál se vysílal mezi lety 19972003) je zde Anita prezentována jako žena, která přestává být $\mathrm{v}$ roli oběti, ale je sama schopna ničit nestvůry, které ji pronásledovaly $\mathrm{v}$ předchozích dekádách upírských i jiných románů. Je zde tedy také možno vidět určitou reakci na proměnu genderových rolí a otevírající se možnosti žen. Stejně tak jako se ženy v moderním světě vyrovnávají mužům v běžných činnostech, projevuje se tato emancipace i ve světě fantasy, v jejich schopnostech přemáhat upíry a bojovat se stvůrami, at' už po boku mužů nebo bez nich. Nejsou žádná omezení, která by bránila $\mathrm{k}$ dosažení jejich cílů, a pokud jich nedosáhnou, dávají si svoji vlastní slabost za vinu: „Nemůžete přece věrit někomu, kdo spí se stvưrami. A ted’ to sama dělám. Já, Anita Blakeová, jsem se zmènila v rozptýlení do rakve" (Hamilton 2010, 158). V příběhu Anity se původní černobílé rozlišení, kdo je nestvưra a kdo je člověk, proměňuje. Anita postupně ztrácí schopnost rozlišit, co je zlo a co dobro a uvědomuje si, že i lidé mohou být netvory a netvoři mohou mít lidské vlastnosti. A že i ona má v sobě mnoho $\mathrm{z}$ netvora, ačkoli je člověk (viz Holland-Toll 2004).

Upírí boom v posledních letech zahltil regály knihkupectví, variace na stejné téma plytkých př́běhů se znova a znova úspěšně prodává. Př́běhy o mocných, dokonalých, oduševnělých, nebezpečných upírech, do kterých se zamilovávají hrdinky ,jako jsou ony“, jsou čtenáŕkami dychtivě vyhledávány. A inovace upírů, které mají zvýšit prodej, spočívají snad jedině ve vzrůstající tendenci, aby scény popisované v knihách byly více vzrušující, více erotické a ve finále více romantické. V čem spočívá přitažlivost upírů? Je zde určitá kulturní fascinace monstry, kde se strach $\mathrm{z}$ nebezpečného spojuje s atraktivitou parazitních existencí, které nám umožní překročit vlastní smrtelnost. Zároveň, v souvislosti s transformací upíra v posledních letech, přinášejí emoce a stávají se v určité rovině lidštější než lidé. Jsou schopni vášnivě milovat, trpět i hluboce nenávidět, cítí nadšení nebo hořký smutek, ale své emoce - na rozdíl od lidí dnešní doby - dokonale neovládají. Pro moderní samostatné ženy jsou tedy pohádkou, kterou mohou prožívat ve světě vědy a techniky - prototypem romantického muže, a romantického vztahu, který, když si ho vybojují, bude trvat na věky věků, $\mathrm{k}$ čemuž zkušená skepse žen a atmosféra současné doby v realitě příliš optimismu nedodává. A tak, jako se muži ve svých fantaziích vydávají do kobek hledat poklady a bojovat s draky, otevírají ženy dveře, kterými dovolují upírům vstoupit do jejich světů.

Fantasy světy jako novodobý sociálně-kulturní fenomén jsou charakteristické určitou jednoznačností, zřejmostí a snadnou 
orientací. Všechny postavy mají své místo, plní svůj úkol, je jim jasné, co mají dělat pro dosažení snů a přání - dobře vědí, kde se setkají s dobrem a kde se zlem. Absence těchto aspektů v moderním světě, spolu s neustále se zrychlujícím technologickým vývojem, potlačováním emocí, se stále menší propojeností s tradicemi, snižuje sebevědomí jedince a identifikaci s jeho rolí v reálném životě. Jak zdůrazňuje rumunský religionista Mircea Eliade (1907-1986), žádná společnost se nemůže zcela oprostit od mýtu, nebot základní rysy mytického chování jsou nerozlučně spojeny s lidským údělem. Mýtus pouze změnil svoji podobu a maskuje své poslání. Podle jeho názoru je moderní člověk ovlivňován neurčitou mytologií, která mu nabízí k napodobování nespočetné vzory skutečných i smyšlených hrdinů a formou různých rozptýlení a zábav mu dává pocit, že „ovládá čas“, čímž mu napomáhá uniknout z nemilosrdné pouti ke smrti. Napodobování archetypů prozrazuje jistou nechut' k vlastní osobní historii a nejasnou touhu po proměně historické a okrajové současnosti, znovudosažení nějaké velké doby a prožívání odlišného časového rytmu (Eliade 1998, 22-23).

\section{LITERATURA}

Borčanyiová, Zuzana (2010): Konstanty a proměnné ve vývoji literárního hororu: Postava upíra. Bakalářská práce. Olomouc: Univerzita Palackého.

Budil, Ivo T. (2007): Za obzor Západu - Promèny antropologického myšlení od Isidora ze Sevilly po Franze Boase. Praha: Triton.

Byliny: Staré ruské bohatýrské písně (1925). Praha: J. Otto.

Campbell, Joseph (2000a): Proměny mýtu v čase: Vývoj mýtů od raných kultur až po středověké legendy. Praha: Portál.

Campbell, Joseph (2000b): Tisíc tvárí hrdiny: Archetyp hrdiny v proměnách věkủ. Praha: Portál.

Carlyle, Thomas (1925): Hrdinové (úcta k hrdinům a hrdinství v dějinách). Praha: Symposion.

Douse, Neil A. - McManus, Ian Chris (1993): The Personality of Fantasy Game Players. British Journal of Psychology, 84(4), 505-509.

Ekumenický překlad Bible (1993). Praha: Česká biblická společnost.

Eliade, Mircea (1998): Mýty, sny a mystéria. Praha: Oikoymenh.

Fromm, Erich (1999): Mýtus, sen a rituál a jejich zapomenutý jazyk. Praha: Aurora.

Hamilton, Laurell K. (2001): Narcissus in Chains. New York: Berkley Books.

Hamilton, Laurell K. (2010): Zápalné oběti. Praha: Triton.

Holland-Toll, Linda J. (2004): Harder than Nails, Harder than Spade: Anita Blake as "The Tough Guy" Detective. The Journal of American Culture, 27(2), 175-89.

Holý, Jakub (2004): Úvod ke zkoumání Her s hraním rolí. Bakalářská práce. Praha: Fakulta humanitních studií Univerzity Karlovy v Praze.

Hornung, Erik (2002): Tajemný Egypt: Kořeny hermetické moudrosti. Praha: Paseka.

Hruška, Blahoslav et al. (1977): Mýty staré Mezopotámie: Sumerská, akkadská a chetitská literatura na klínopisných tabulkách. Praha: Odeon.

Janeček, Petr (2002): Paralelní světy (kulturní fenomén her na hrdiny pohledem etnologie). Bakalářská práce. Praha: Univerzita Karlova v Praze.

Jung, Carl Gustav (1997): Výbor z díla II.: Archetypy a nevědomí. Brno: Nakladatelství Tomáše Janečka.

Justoň, Zdeněk (1997): Setkání Lévi-Strausse s Tolkienem. Praha: Dauphin.

Kamberský, Petr (1994): Prolínání světů. Bakalářská práce. Praha: Univerzita Karlova v Praze.

Klímová, Dagmar (1998): Strašidelná pohádka jako národopisný fenomén. Českýlid, 85(4), 341-351.
Krajhanzl, Jan (2001): Psychologické aspekty fantasy Role-playing games. Kvantitativní a kvalitativní výzkum. Seminární práce pro předmět Psychologická metodologie. Praha: Univerzita Karlova v Praze.

Le Fanu, Joseph Sheridan (2010): Carmilla. Bratislava: Európa, s.r.o.

Leppälahti, Merja (2003): Gender play? Platiny Man and Woman in RolePlaying Games. (online). http://www.iiav.nl.

Mádrová, Evženie (2004): Osobnost a volba postavy ve fantasy RPG hrách. Diplomová práce. Praha: Univerzita Karlova v Praze.

Maiello, Giuseppe (2004): Vampyrismus v kulturních dějinách Evropy. Praha: Nakladatelství Lidových novin.

Neubauer, Zdeněk (1992): Do světa na zkušenou čili O cestách tam a zase zpátky (Malá rukovět k trilogii J. R. R. Tolkiena Hobit - Pán prstenů - Silmarillion). Praha: Michal Jůza \& Eva Jůzová.

Pernica, Alexej (2003): Mýtové kořeny dramatických postav. Brno: Janáčkova akademie múzických umění v Brně.

Polidori, John William (1819): The Vampire. (online). http://www.gutenberg org.

Popol Vuh (1976). Praha: Odeon.

Rice, Anne (1996): Interview s upírem. Praha: Cinema - Paseka.

Sapkowski, Andrzej (2008): Hranice možností. In: Zaklínač II.: Meč osudu. Ostrava: Leonardo, 5-71.

Senf, Carol A. (1982): "Dracula”: Stoker's Response to the New Woman. Victorian Studies, 26(1), 33-49.

Smith, Grafton Elliot (1909): The Evolution of the Dragon (online). http:// www.gutenberg.org.

Stanton, Michael N. (2003): Hobiti, elfové a čarodějové. Praha: Mladá fronta.

Stoker, Bram (1970): Dracula. Praha: Odeon.

Šalanda, Bohuslav (1998): Hrdinové a hrdinství v dějinách. Studia etnographica IX. Praha: Karolinum, 97-107.

Tolkien, John Ronald Reuel (1997): Př́běhy z čarovné řišse. Praha: Mladá fronta.

Tolkien, John Ronald Reuel (2005): Hobit aneb Cesta tam a zase zpátky. Praha: Argo.

Vágner, Ivan (1995): Svět postmoderních her. Jinočany: H\&H.

Warner, Elizabeth (2006): Ruské mýty. Praha: Levné knihy KMa.

Weber, Max (1998): Metodologie, sociologie a politika. Praha: Oikomenh.

Williamson, Milly (2005): The Lure of the Vampire: Gender, Fiction and Fandom from Bram Stoker to Buffy. London: Wallflower Press.

Wood, Martin J. (1999): New Life for an Old Tradition: Anne Rice and Vampire Literature. In: Heldreth, Leonard G., ed., The Blood Is the Life: Vampires in Literature. Ohio: Bowling Green State University Popular Press, 59-78.

Zamarovský, Vojtěch (2005): Bohové a hrdinové antických bájí. Praha: Brána.

Zbíral, David (2003): Žánr fantasy a religionistika: Možnosti, meze, provokace. (online). http://mujweb.cz/www/david.zbiral.

\section{AUTORKA}

Poláková, Markéta (3. 5. 1983, Praha), česká kulturoložka, absolventka Katedry teorie kultury Filozofické fakulty Univerzity Karlovy v Praze. Předmětem jejího výzkumného zájmu je problematika genderu a kultury v perspektivě feministické antropologie a Gender Studies. Stěžejním tématem jejích studií je analýza obrazu muže a ženy v současné západní společnosti. Zabývá se také analýzou vlivu médií a nových technologií na formování genderové identity. Diplomová práce (2007): Mužský a ženský princip v transkulturní perspektivě (gender, sexualita, kultura). Disertační práce (2011): Gender, identita, kultura.

Kontakt: Mgr. Markéta Poláková, Ph.D., Katedra teorie kultury (kulturologie) Filozofické fakulty Univerzity Karlovy v Praze, Celetná 20, 11000 Praha 1, e-mail: marketa.polak@seznam.cz 
